\title{
Total Knee Arthroplasty pada Rheumatoid Arthritis
}

\section{Total Knee Arthroplasty in Rheumatoid Arthritis}

\author{
Ahmad Fauzi ${ }^{1}$, Andri Maruli $\mathrm{TL}^{2}$ \\ ${ }^{1}$ Bagian Bedah Divisi Orthopaedi dan Traumatologi Fakultas Kedokteran Universitas Lampung Lampung \\ ${ }^{2}$ Bagian Bedah Divisi Orthopaedi dan Traumatologi Fakultas Kedokteran Universitas Indonesia Jakarta
}

\begin{abstract}
ABSTRAK
Lutut adalah salah satu sendi yang paling sering terkena rheumatoid arthritis (RA). Total knee arthroplasty (TKA) merupakan intervensi yang paling sukses mengurangi nyeri lutut dan meningkatkan fungsi lutut pada RA stadium lanjut. Kami laporkan kasus tiga pasien wanita dengan kerusakan lutut berat akibat RA sekunder yang dikelola dengan fixedbearing prosthesis Zimmer's NexGen. Pasien pertama adalah seorang wanita berusia 45 tahun yang menderita RA pada kedua lutut dengan Knee society score (KSS) pada lutut kanan 40 dan pada lutut kiri 38. Pasien kedua adalah seorang wanita berusia 46 tahun yang menderita RA pada lutut kiri dengan KSS 50. Pasien ketiga, wanita berusia 35 tahun dengan KSS 40. Setelah melakukan TKA, skor KSS pasien pertama meningkat menjadi 77 pada kedua lutut. Demikian juga pada pasien kedua dan ketiga, skor KSS menjadi 70. Dari kasus ini dapat disimpulkan bahwa TKA meningkatkan fungsi secara keseluruhan serta kualitas hidup pasien dengan RA lutut.
\end{abstract}

Kata Kunci: Lutut, rheumatoid arthritis, total knee arthroplasty

\begin{abstract}
Knee is one of the joints most commonly affected by rheumatoid arthritis (RA). Total knee arthroplasty (TKA) is the most successful intervention to reduce knee pain and improve physical function at an advanced stage RA. We reported cases of three female patients with advanced knee joint destruction due to secondary RA managed with fixed-bearing prosthesis Zimmer's NexGen. The first patient was a 45-year-old woman suffering from RA in both knees with Knee Society Score (KSS) 40 on the right knee and 38 on the left knee. The second patient was a 46-year-old woman suffering from RA in the left knee with KSS 50. Patients the third, a woman aged 35 years with KSS 40. After performing TKA, the first patient KSS score rose to 77 on both knees. Also for the second and third patients, where KSS score became 70. Of these cases, it can be concluded that the TKA improve overall function and quality of life of patients with RA on knee.
\end{abstract}

Keywords: Knee, rheumathoid arthritis, total knee arthoplasty

Korespondensi: Ahmad Fauzi. Bagian Bedah Divisi Orthopaedi dan Traumatologi Fakultas Kedokteran Universitas Lampung, Jl. Prof. Dr. Ir. Sumantri Brojonegoro No. 1, Lampung Tel. (0721) 7691197 Email:ahmadfauzi_dr@yahoo.co.id 


\section{PENDAHULUAN}

Rheumatoid arthritis (RA) adalah penyakit inflamasi autoimun-sistemik, progresif dan kronis yang mempengaruhi banyak jaringan dan organ, namun pada prinsipnya merusak sendi-sendi sinovial. Proses inflamasi ini seringkali berujung pada kerusakan tulang rawan sendi dan ankilosing sendi. Karakteristik yang paling sering ditemui adalah polyarthritis simetris dan tenosinovitis, morning stiffness, peningkatan laju endap darah (LED), serta gambaran autoantibodi dengan target immunoglobulin (faktor rheumatoid) dalam serum (1).

Prevalensi RA yang dilaporkan pada sebagian besar populasi adalah 1-3 \%, dengan insiden puncak pada dekade keempat atau kelima. Wanita 3-4 kali lebih sering mengalami RA dibandingkan pria. Penyebab RA sampai saat ini belum diketahui secara pasti. Beberapa faktor yang diduga menjadi penyebab RA antara lain: faktor genetik, reaksi inflamasi pada sendi dan selubung tendon, faktor rheumatoid, sinovitis kronis dan destruksi sendi, gender dan infeksi (1).

Tujuan terapi RA adalah mengurangi nyeri dan pembengkakan pada sendi, menghilangkan kekakuan sendi, dan mencegah kerusakan sendi lebih lanjut. Pemilihan terapi RA dengan menggunakan NSAIDs (Nonsteroidal Anti Inflammatory Drugs) atau COX-2 inhibitor sebagai NSAID spesifik merupakan terapi lini pertama pada RA. Bila RA menjadi agresif meskipun telah menjalani terapi menggunakan NSAID, maka dapat digunakan terapi pengobatan lini kedua dalam 3 hingga 6 bulan. Methotrexate dapat digunakan sebagai terapi pada pasien RA dengan manifestasi klinis yang jelas (erosi, keterlibatan banyak sendi, manifestasi ekstraartikuler) dengan dikombinasikan dengan hydroxychloroquine atau sulfalazine (2).

Indikasi pembedahan pada RA adalah kegagalan terapi medikamentosa, nyeri dan kaku sendi yang berat, baik dengan aktivitas ataupun istirahat, atau adanya penurunan fungsi yang mengganggu aktivitas sehari-hari pasien (1,2). Total Knee Arthroplasty (TKA) merupakan tindakan pembedahan yang cukup efektif pada kasus arthritis lutut yang berat. Arthritis lutut berat menimbulkan nyeri yang hebat pada pasien dan menimbulkan disfungsi sendi serta penurunan kualitas hidup. Pada umumnya TKA diindikasikan pada pasien berusia lanjut yang memiliki aktivitas yang lebih sederhana dibandingkan dengan pasien usia muda, serta bila terapi medikamentosa tidak memberikan perbaikan yang signifikan $(2,3)$. Kasus serial ini kami laporkan mengingat kasus ini jarang ditemukan pada usia muda dan memerlukan penatalaksanaan bedah. Evaluasi keberhasilan TKA di lakukan dengan menggunakan knee society score (3).

\section{KASUS}

\section{Kasus 1}

Wanita usia 45 tahun datang ke Klinik Orthopaedi RSUPN Cipto Mangunkusumo (RSCM) dengan keluhan sendi lutut kaku sejak 6 tahun yang lalu. Sejak 6 tahun yang lalu pasien mengeluh pegal-pegal di kedua kaki dan tangan yang dirasakan hilang timbul. Pasien kemudian berobat ke dokter umum dan dikatakan menderita rematik. Pasien sempat mendapatkan terapi yang diberikan dengan cara injeksi ebanyak $\pm 12 x$ namun keluhan tidak berkurang. Kaki pasien terasa semakin nyeri dan kaku sejak 1 tahun yang lalu, khususnya pada lutut. Kekakuan ini dirasakan di kedua sisi tungkai atas dan bawah. Pasien kemudian berobat ke poliklinik Orthopaedi RSCM.

Pada pemeriksaan fisik kedua sendi lutut ditemukan pembengkakan, nyeri tekan minimal, dan krepitasi. Tidak didapatkan deformitas pada sendi lutut. Pasien memiliki keterbatasan dalam melakukan fleksi lutut kanan 40$100^{\circ}$, sedangkan fleksi lutut kiri terbatas $45-90^{\circ}$. Nilai Knee Society Score 40 (lutut kanan) dan 38 (lutut kiri). Pada pemeriksaaan laboratorium darah lengkap, didapatkan hasil dalam batas normal. Melalui analisis Patologi Klinik tidak ditemukan kuman gram (+) maupun gram (-). Pada pemeriksaan laboratorium lainnya menunjukkan bahwa nilai Rheumatoid Factor: 209U/ml, C-Reactive Protein $28,3 \mathrm{mg} / \mathrm{L}$.

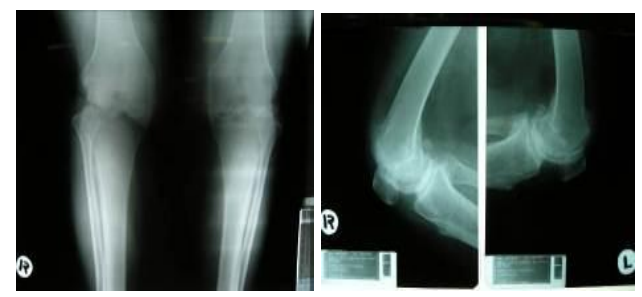

Gambar 1. Gambaran radiologis pre operasi lutut, proyeksi antero-posterior dan lateral

Keterangan: Tampak kedua sendi lutut memiliki celah sendi yang menyempit, sklerosis, dengan proses osteoporosis subchondral, dan ditemukan adanya pembentukan osteofit. Tidak tampak adanya erosi atau destruksi tulang.

Pada pemeriksaan penunjang radiologis manus dextra dan sinistra didapatkan osteoporosis subchondral yang disertai penyempitan celah sendi interfalangeal (Gambar 1). Dari pemeriksaan radiologis genu dextra dan sinistra, didapatkan bahwa kedua sendi lutut memiliki celah sendi yang menyempit, dengan proses osteoporosis subchondral, dan ditemukan adanya pembentukan osteofit. Pada pemeriksaan awal, dilakukan pemeriksaan aspirasi cairan sendi pada kedua lutut dengan didapatkan hasil ditemukan koloni Klebsiella pneumonia.

Dari anamnesis, pemeriksaan fisik, dan pemeriksaan penunjang yang telah dilakukan, pasien ini didiagnosis sebagai RA. Pasien telah menjalani terapi medikamentosa dengan Cefipim 1gram yang diberikan dua kali, namun progresifitas destruksi sendi semakin memberat, sehingga pada pasien ini diputuskan untuk melakukan Total Knee Arthroplasty (TKA) dalam 2 tahap. Pasien menjalani operasi TKA pada lutut sisi kiri terlebih dahulu, dan operasi TKA pada lutut kanan 4 bulan setelahnya. TKA yang digunakan ialah dengan menggunakan prosthesis Nexgen ${ }^{\circledR}$ dengan bone cement. Dari operasi ini diambil sebagian jaringan tulang rawan untuk pemeriksaan histopatologi di bagian Patologi Anatomi FKUI/RSCM.

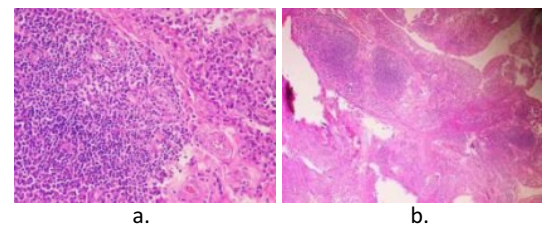

Gambar 2. Gambar histopatologi (a) Sel plasma, (b) Jaringan limfoid, (c) Sel-sel PMN, (d) Pertumbuhan papiler 


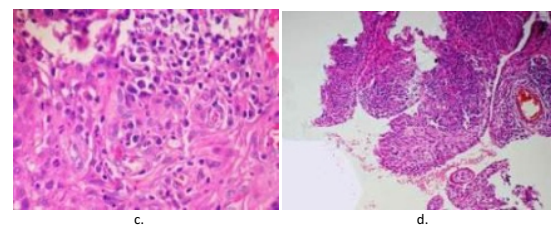

Gambar 2. Gambar histopatologi (a) Sel plasma, (b) Jaringan limfoid, (c) Sel-sel PMN, (d) Pertumbuhan papiler (Lanjutan)

Hasil pemeriksaan histopatologi sediaan yang terdiri dari jaringan sinovial memperlihatkan gambaran hiperplasia sel sinovial, penumbuhan papiler, serbukan sel netrofillimfosit-dan sel plasma, pembentukan folikel limfoid, dan terdapat sebagian jaringan nekrosis (Gambar 2). Dari deskripsi tersebut, disimpulkan bahwa secara histologik sesuai dengan gambaran pada RA.

Pasca operasi, pasien menjalani continous passive motion (CPM) setiap kali pasien selesai menjalani tindakan operasi TKA. Pasca operasi, pasien dapat mengekstensikan penuh lututnya dan tidak dirasakan adanya gangguan pada saat pasien melakukan fleksi lutut. Pasien tidak lagi mengeluh adanya kaku sendi, keluhan tidak dapat meluruskan(lutut kanan dan kiri). Setelah 2 tahun pasca operasi, hingga saat ini pasien mengonsumsi Methotrexate 10mg dalam 1 minggu, dan sudah tidak mengonsumsi obat analgetika karena pasien tidak mengeluh nyeri kembali.

\section{Kasus 2}

Wanita usia 46 tahun datang ke Klinik Orthopaedi RSUPN Cipto Mangunkusumo dengan keluhan nyeri pada lutut kiri sejak 13 tahun yang lalu. Sejak 13 tahun yang lalu pasien mulai mengeluh nyeri di lutut kiri, pergelangan tangan dan bahu, keluhan dirasakan hilang timbul. Pasien berobat ke dokter umum dan dikatakan menderita rematik. Kemudian pasien diberi obat namun keluhan tidak membaik. Tiga tahun yang lalu pasien mengeluh nyeri pada lutut dirasakan semakin berat dengan sendi lutut bertambah kaku. Pasien mengeluh sulit untuk berjalan dan memulai aktifitas. Pasien harus menggunakan tongkat untuk berjalan. Pasien juga mengeluh kesulitan dalam melakukan aktifitas seharihari.

Dari pemeriksaan fisik sendi lutut kiri ditemukan deformitas valgus, kontraktur fleksi sendi, nyeri tekan yang minimal, dan krepitasi. Pasien memiliki keterbatasan dalam melakukan fleksi lutut kiri yaitu $0-110^{\circ}$. Nilai Knee Society Score 60. Pemeriksaan fisik pada kedua pergelangan tangan ditemukan pembengkakan dan keterbatasan gerak fleksi dan ekstensi. Tidak ditemukan deformitas maupun luka pada pergelangan tangan.
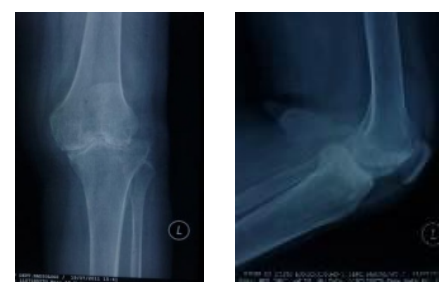

Gambar 3. Gambaran radiologis pre operasi lutut, proyeksi antero-posterior, lateral, dan skyline

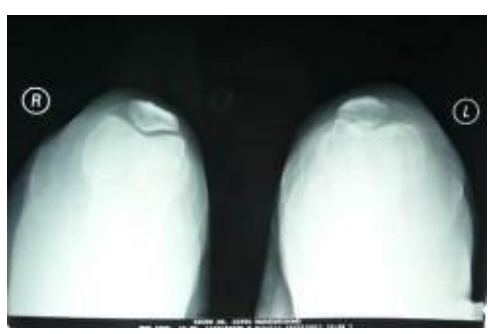

Gambar 3. Gambaran radiologis pre operasi lutut, proyeksi antero-posterior, lateral, dan skyline (Lanjutan)

Keterangan: Tampak deformitas valgus, celah sendi yang menyempit, dengan proses osteoporosis subchondral, dan destruksi permukaan sendi serta ditemukan adanya pembentukan osteofit

Pada pemeriksaaan laboratorium darah lengkap pasien tidak ditemukan adanya kelainan. Pada pemeriksaan laboratorium lainnya menunjukkan peningkatan nilai rheumatoid factor: $110 \mathrm{U} / \mathrm{ml}$ (normal <14), C-Reactive Protein 17,4mg/L (normal 0,0-0,5). Hasil pemeriksaan penunjang radiologis manus dextra dan sinistra menunjukkan tulang-tulang tampak utuh (intak), namun didapatkan osteoporosis subchondral yang disertai penyempitan celah sendi interfalangeal. Dari pemeriksaan radiologis genu sinistra, didapatkan deformitas valgus, celah sendi yang menyempit, dengan proses osteoporosis subchondral, dan destruksi permukaan sendi serta ditemukan adanya pembentukan osteofit (Gambar 3).

Pasien telah menjalani terapi medikamentosa namun progresifitas destruksi sendi semakin memberat, sehingga pada pasien ini diputuskan untuk dilakukan TKA. Paska operasi, pasien menjalani CPM. Pada pemeriksaan fisik, pasien dapat mengekstensikan penuh lututnya dan tidak dirasakan adanya gangguan pada saat pasien melakukan fleksi lutut. Pasien tidak lagi mengeluh adanya kaku sendi, keluhan tidak dapat meluruskan kakinya, ataupun nyeri yang berat pada kedua lututnya. Nilai knee society score 70 dan saat ini pasien tidak mengeluh nyeri kembali.

\section{Kasus 3}

Wanita usia 35 tahun datang ke Klinik Orthopaedi RSUPN Cipto Mangunkusumo dengan keluhan nyeri pada lutut kanan sejak 5 tahun yang lalu. Sejak 5 tahun yang lalu pasien mengeluh mulai merasa nyeri di kedua lutut dan pergelangan tangan, keluhan dirasakan hilang timbul. Pasien berobat ke dokter umum dan dikatakan menderita rematik, kemudian pasien diberi obat namun keluhan tidak membaik. Pasien mengeluh nyeri pada lutut kanan dirasakan semakin berat. Tujuh bulan kemudian pasien mengeluh nyeri pada lutut kanan semakin hebat dan mulai kaku. Pasien mengeluh sulit untuk berjalan dan memulai aktifitas. Nyeri dirasakan terutama saat naik dan turun tangga. Saat ini pasien harus menggunakan walker untuk berjalan. Pasien juga mengeluh kesulitan dalam melakukan aktifitas sehari-hari seperti menulis, memasak, dan memasang kancing.

Dari pemeriksaan fisik sendi lutut kanan ditemukan deformitas varus, pembengkakan, kontraktur fleksi sendi, nyeri tekan yang minimal, dan krepitasi. Pasien memiliki keterbatasan dalam melakukan fleksi lutut kanan yaitu 40$90^{\circ}$. Nilai Knee Society Score 40. Pemeriksaan fisik pada kedua pergelangan tangan ditemukan pembengkakan dan keterbatasan gerak fleksi dan ekstensi. Tidak ditemukan deformitas maupun luka pada pergelangan tangan. 


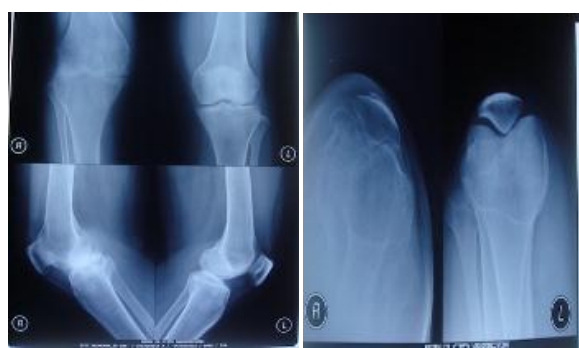

Gambar 4. Gambaran radiologis pre operasi lutut, proyeksi antero-posterior, lateral dan skyline

Keterangan: pada lutut kanan tampak deformitas varus, celah sendi yang menyempit, dengan proses osteoporosis subchondral, dan destruksi permukaan sendi serta ditemukan adanya pembentukan osteofit

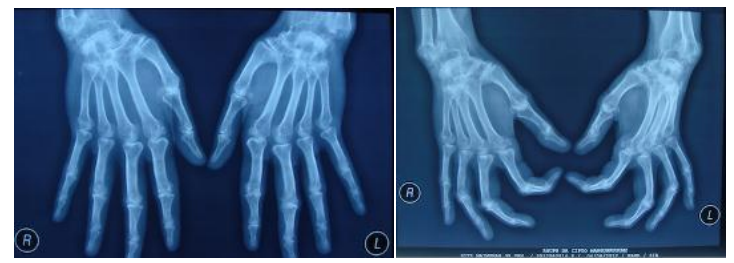

Gambar 5. Gambaran radiologis kedua tangan

Keterangan: Tampak tulang-tulang intak, didapatkan osteoporosis subchondralyang disertai penyempitan celah sendi interfalangeal

Hasil pemeriksaaan laboratorium darah lengkap pasien dalam batas normal. Pada pemeriksaan laboratorium lainnya menunjukkan bahwa nilai rheumatoid factor: $22,6 \mathrm{U} / \mathrm{ml}$ (normal <14), C-Reactive Protein $0,7 \mathrm{mg} / \mathrm{L}$ (normal 0,0-0,5). Pada pemeriksaan penunjang radiologis manus dextra dan sinistra didapatkan osteoporosis subchondral yang disertai penyempitan celah sendi interfalangeal. Dari pemeriksaan radiologis genu dextra, didapatkan deformitas varus, celah sendi yang menyempit, dengan proses osteoporosis subchondral, dan destruksi permukaan sendi serta ditemukan adanya pembentukan osteofit (Gambar 4 dan Gambar 5).

Dari anamnesis, pemeriksaan fisik, dan pemeriksaan penunjang yang telah dilakukan, pasien ini didiagnosis sebagai RA bilateral. Pasien telah menjalani terapi medikamentosa namun progresifitas destruksi sendi semakin memberat, sehingga pada pasien ini diputuskan untuk melakukan TKA. Pasca operasi, pasien menjalani CPM. Pasien dapat mengekstensikan penuh lututnya dan tidak dirasakan adanya gangguan pada saat pasien melakukan fleksi lutut. Pasien tidak lagi mengeluh adanya kaku sendi, keluhan tidak dapat meluruskan kakinya, ataupun nyeri yang berat pada kedua lututnya. Nilai knee society score 70. Saat ini pasien tidak mengeluh nyeri kembali.

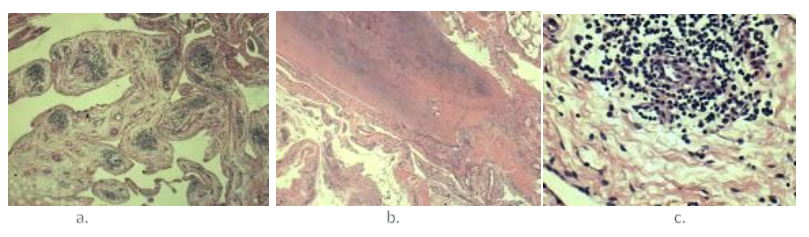

\section{Gambar 6. Gambar Histopatologi}

Keterangan: (a) Sel Plasma dan pertumbuhan papiler, (b) Jaringan Limfoid, (c) Sel-Sel PMN

Hasil pemeriksaan histopatologi didapatkan hasil sediaan yang terdiri dari jaringan sinovial yang memperlihatkan gambaran: hiperplasia sel sinovial, penumbuhan papiler, sebukan sel netrofil-limfosit-dan sel plasma, pembentukan folikel limfoid, dan terdapat sebagian jaringan nekrosis (Gambar 6). Dari deskripsi tersebut, disimpulkan bahwa secara histologik sesuai dengan gambaran pada Rheumatoid Arthritis.

Secara umum, karakteristik ketiga kasus di atas, dapat dirangkum dalam Tabel 1. Kasus ketiga menunjukkan gambaran yang berbeda yaitu lebih muda, gambaran laboratorium yang lebih baik dengan masa follow up yang lebih pendek pula. Meskipun demikian terapi yang diberikan sama pada ketiga pasien dengan luaran yang sama pula.

\section{DISKUSI}

Rheumatoid arthritis adalah penyakit inflamasi autoimunsistemik, progresif, dan kronis yang mempengaruhi banyak jaringan dan organ, namun pada prinsipnya merusak sendi-sendi sinovial. Penyebab utama RA masih belum diketahui, namun beberapa referensi menyebutkan bahwa infeksi memiliki peran dalam patofisiologi RA. Gejala dari RA termasuk perubahan dengan menimbulkan respon inflamasi pada membran sinovium dan struktur artikuler disekitarnya, yaitu tulang rawan sendi, dan juga tulang-

Tabel 1. Rangkuman karakteristik kasus

\begin{tabular}{|c|c|c|c|}
\hline Karakteristik & Kasus 1 & Kasus 2 & Kasus 3 \\
\hline Jenis Kelamin & Wanita & Wanita & Wanita \\
\hline Usia & 45 tahun & 46 tahun & 35 tahun \\
\hline Lama sakit & 6 tahun & 13 tahun & 5 tahun \\
\hline $\begin{array}{l}\text { Rheumatoid Factor (Normal < } \\
\text { 14) }\end{array}$ & $209 \mathrm{U} / \mathrm{ml}$ & $110 \mathrm{U} / \mathrm{ml}$ & $22,6 \mathrm{U} / \mathrm{ml}$ \\
\hline $\begin{array}{l}\text { C-Reactive Protein (Normal } \\
0,0-0,5 \text { ) }\end{array}$ & $28,3 \mathrm{mg} / \mathrm{L}$ & $17,4 \mathrm{mg} / \mathrm{L}$ & $0,7 \mathrm{mg} / \mathrm{L}$ \\
\hline Sendi lutut yang terdestruksi & Bilateral & Lutut kiri & Lutut kanan \\
\hline KSS sebelum TKA & $\begin{array}{l}\text { Kanan : } 40 \\
\text { Kiri : } 38\end{array}$ & 60 & 40 \\
\hline KSS setelah TKA & $\begin{array}{c}\text { Kanan : } 77 \\
\text { Kiri : } 77\end{array}$ & 70 & 70 \\
\hline Lama follow up & 2 tahun & 1 tahun & 6 bulan \\
\hline DMARDs & $\begin{array}{c}\text { Methotrexate } 10 \mathrm{mg} \text { dalam } 1 \\
\text { minggu }\end{array}$ & $\begin{array}{c}\text { Methotrexate } 10 \mathrm{mg} \text { dalam } 1 \\
\text { minggu }\end{array}$ & $\begin{array}{c}\text { Methotrexate } 10 \mathrm{mg} \text { dalam } 1 \\
\text { minggu }\end{array}$ \\
\hline
\end{tabular}


Tabel 1. Rangkuman karakteristik kasus (Lanjutan)

\begin{tabular}{|c|c|c|c|}
\hline Karakteristik & Kasus 1 & Kasus 2 & Kasus 3 \\
\hline $\begin{array}{l}\text { Konsumsi analgetika jangka } \\
\text { panjang pasca operasi }\end{array}$ & Tidak ada & Tidak ada & Tidak ada \\
\hline Keluhan pasca TKA & Nyeri (-), Kaku (-) & Nyeri (-), Kaku (-) & Nyeri (-), Kaku (-) \\
\hline Komplikasi pasca operasi & Tidak ada & Tidak ada & Tidak ada \\
\hline
\end{tabular}

tulang di bawahnya. Proses RA pada lutut biasanya terjadi bilateral dan simetris, semakin lama menimbulkan nyeri yang hebat, deformitas, dan ketidakmampuan pasien dalam beraktivitas, bahkan berjalan (1).

Pada ketiga pasien dalam studi kasus ini mengeluhkan nyeri yang dirasakan semakin lama semakin hebat, hingga pasien tidak dapat berjalan ataupun bahkan tidak mampu meluruskan kakinya secara penuh. Nilai knee society score sebelum operasi pada ketiga pasien kurang dari 60 . Dengan keterbatasan fleksi lutut, dan gambaran radiologis yang menunjukkan destruksi sendi lutut (osteoporosis subchondral, penyempitan celah sendi, pembentukan osteofit). Didukung dengan nilai rheumatoid factor yang meningkat, dan nilai $C$-reactive protein yang meningkat, maka ketiga pasien kami diagnosis sebagai rheumatoid arthritis sesuai kriteria diagnosis American Rheumatology Association sehingga pasien dilakukan tindakan TKA $(1,4)$.

Hal yang perlu diperhatikan dalam tindakan TKA adalah mengatasi permasalahan perioperatif yang dapat terjadi. Pada ketiga pasien diberikan terapi antibiotik cephalosporin generasi 4. Pada persiapan TKA, prostesis yang dipilih adalah fixed-bearing nexgen ${ }^{\circledR}$ dengan menggunakan semen tulang (bone cement), dengan berdasarkan penilaian intraoperatif bahwa tulang dinilai tidak osteoporotik. Pasien telah memahami informed consent yang disampaikan oleh tim orthopaedi, bahwa proses RA masih berlangsung, dan resiko osteoporosis tetap tinggi pada pasien ini, sehingga bisa diperlukan suatu tindakan revisi TKA di masa mendatang $(5,6)$.

Setelah menjalani operasi, pasien lalu berobat ke Klinik Rheumatologi RSCM, dan diberikan terapi methotrexate dan analgetika. Dosis yang diberikan hingga saat ini (2 tahun paska operasi) adalah $10 \mathrm{mg}$ methotrexate dalam 1 minggu. Methotrexate merupakan agen terapi RA yang tergabung dalam kelompok disease-modifying antirheumatic drugs (DMARDs) yang digunakan untuk terapi rheumatoid arthritis untuk memperlambat progresifitas $\operatorname{RA}(7,8)$.

Pada ketiga kasus ini, pasien memang tidak diberikan methotrexate sebelum operasi. Menurut beberapa studi penelitian bahwa pemberian methotrexate yang tidak diberhentikan selama perioperatif dapat menimbulkan komplikasi infeksi paska operasi, baik itu adalah infeksi sendi, atau tidak optimalnya prosthesis atau implan. Pasien dengan terapi methotrexate yang tidak diberhentikan sama sekali selama periode perioperatif TKA dengan pasien yang methotrexate diberhentikan 1

\section{DAFTAR PUSTAKA}

1. Warwick DJ, Solomon L, and Nayagam S. Apley's System of Orthopaedics and Fractures. 8th edition. Great Britain: Arnold; 2001: pp. 409-416.

2. Clair EW, Pisetsky DS, and Haynes BF. Rheumatoid minggu sebelum operasi dan diberikan kembali 1 minggu setelah operasi, menunjukkan hasil yang berbeda. Infeksi lebih banyak timbul pada kelompok yang pertama. Pemberian Metotrexate pada pasien ini dilakukan paska operasi, dan pemberian yang rutin selama 2 tahun menunjukkan hasil yang baik. Hal ini juga didukung dengan pemeriksaan evaluasi paska operasi pada pasien ini, bahwa tidak adanya keluhan mual, muntah yang menetap, dan pemeriksaan laboratorium darah menujukkan tidak adanya peningkatan enzim hati $(7,8)$.

Standar follow up untuk kasus rheumatoid arthritis yang dilakukan TKA belum ada, sehingga penulis menentukan batasan follow up dengan membandingkan keluhan sebelum operasi berupa nyeri dan kaku sendi dan knee society score dengan pasca operasi, serta komplikasi yang mungkin terjadi. Follow up dilakukan pada bulan ke-6, tahun ke-1 dan tahun ke-2 pasca operasi. Ketiga pasien mendapatkan terapi medikamentosa yang sama. Pada laporan kasus ini, baik kasus 1, 2 dan 3, keluhan yang ada sebelum operasi tidak lagi didapatkan seudah operasi. Komplikasi pasca operasi pada pasien RA berupa osteolisis, infeksi dan periphrostetic fracture juga tidak didapatkan pada ketiga pasien. Dua tahun pasca operasi, pasien dapat berjalan dan melakukan aktivitas sehari-hari tanpa keluhan nyeri, dan tanpa obat analgetika. Saat ini, sesuai standar terapi Divisi Rheumatologi RSCM, pasien mendapatkan terapi methotrexate $10 \mathrm{mg} /$ minggu. Hingga saat ini pasien rutin memeriksakan diri ke Divisi Rheumatologi dan Orthopaedi RSCM untuk evaluasi klinis. Menurut beberapa referensi, pemberian methotrexate tetap dievaluasi setiap 4-8 minggu meskipun pasien tidak mengutarakan keluhan pada kedua lututnya (2,7-10).

Pasca operasi TKA pasien mengalami perbaikan fungsi sendi lutut yang signifikan dan pasien dapat berjalan, dengan knee society score di atas 60 . Hingga saat ini (2 tahun pasca operasi) pasien tidak mengkonsumsi obat analgetika lagi. Pasien masih melakukan pemeriksaan rutin di Divisi Rheumatologi dan Orthopaedi RSCM, Jakarta. Berdasarkan laporan kasus ini, penulis dapat menyarankan untuk melakukan tindakan operasi pada penderita TKA apabila terapi konservatif gagal dan pasien tidak mengalami perbaikan secara klinis. Umumnya TKA dilakukan pada usia tua dengan kondisi osteoarthritis (OA) lutut stadium lanjut (Kellgren Lawrence grade 4). Berbeda dengan OA, Rheumatoid arthritis dapat terjadi pada usia relatif lebih muda, sehingga TKA yang umumnya dilakukan pada usia lanjut dapat dilakukan pada usia yang lebih muda.

Arthritis. 1st edition. Durham, North Carolina: Lippincott-Williams-Wilkins; 2004.

3. Yano K, Ikari K, Inoue E, et al. Effect of Total Knee Arthroplasty on Disease Activity in Patients with Established Rheumatoid Arthritis: 3-Year Follow-Up 
Results of Combined Medical Therapy and Surgical Intervention. Modern Rheumatology. 2010; 20(5): 452-457.

4. Arnett FC, Edworthy SM, Bloch DA, et al. The American Rheumatism Association 1987 Revised Criteria for the Classification of Rheumatoid Arthritis. Arthritis Rheumatism. 1988; 31(3): 315-324.

5. Kim YH and Kim JS. Does TKA Improve Functional Outcome and Range of Motion in Patients with Stiff Knees? Clinical Orthopaedics and Related Research. 2009; 467(5): 1348-1354.

6. Trieb K, Schmid M, Stulnig T, Huber W, and Wanivenhaus A. Long-term Outcome of Total Knee Replacement in Patients with Rheumatoid Arthritis. Joint Bone Spine. 2008; 75(2): 163-166.

7. Bridges SL and Moreland LW. Perioperative Use of
Methotrexate in Patients with Rheumatoid Arthritis Undergoing Orthopaedic Surgery. Rheumatic Disease Clinics of North America. 1997; 23(4): 981-993.

8. Bongratz T. Elective Orthopaedic Surgery and Perioperative DMARD Management: Many Questions, Fewer Answers, and Some Opinions. The Journal of Rheumatology. 2007; 34(4): 653-655.

9. Momohara S, Inoue E, Ikari K, et al. Efficacy of Total Joint Arthroplasty in Patients with Established Rheumatoid Arthritis: Improved Longitudinal Effects on Disease Activity but not on Health-Related Quality of Life. Modern Rheumatology. 2011; 21(5): 476-481.

10. Wakabayashi H, Hasegawa M, Yoshida K, Nishioka K, and Sudo A. Hip Score and Disease Activity Correlation in Patients with Rheumatoid Arthritis after Total Hip Arthroplasty. International Orthopaedics. 2013; 37(7): 1245-1250. 